\title{
MEDIUM AND LARGE-BODIED MAMMALS OF THE PRIVATE RESERVE OF NATURAL HERITAGE RECANTO DAS ANTAS, IN ESPÍRITO SANTO, BRAZIL
}

\author{
Andressa Gatti ${ }^{1,2 *}$, Paula Modenesi Ferreira ${ }^{1,2}$, Cristina Jaques da Cunha ${ }^{2,3}$, \\ Jardel Brandão Seibert ${ }^{2,4}$ \& Danielle de Oliveira Moreira ${ }^{2,4}$
}

\begin{abstract}
${ }^{1}$ Universidade Federal do Espírito Santo (UFES), Centro de Ciências Humanas e Naturais, Departamento de Ciências Biológicas. Avenida Fernando Ferrari, 514, Goiabeiras, Vitória, Espírito Santo, Brasil. CEP: 29.075-910

${ }_{2}^{2}$ Instituto de Ensino, Pesquisa e Preservação Ambiental Marcos Daniel (IMD). Rua Fortunato Ramos, 123, Santa Lúcia, Vitória, Espírito Santo, Brasil. CEP: 29055-290

${ }^{3}$ Universidade de Vila Velha (UVV), Programa de Pós-Graduação em Ecologia de Ecossistemas. Avenida Comissário José Dantas de Melo, 21, Boa Vista, Vila Velha, Espírito Santo, Brasil. CEP: 29102-920

${ }^{4}$ Universidade Federal do Espírito Santo (UFES), Centro de Ciências Humanas e Naturais, Programa de Pós-Graduação em Ciências Biológicas (PPGBAN). Avenida Fernando Ferrari, 514, Goiabeiras, Vitória, Espírito Santo, Brasil. CEP: 29.075-910

E-mails: gatti.andressa@gmail.com, paulamodenesif@gmail.com, cristinajaques.bio@gmail.com, jardelseibert@gmail.com, daniomoreira@gmail.com
\end{abstract}

\begin{abstract}
In Brazil, Private Reserves of Natural Heritage (RPPN) support protection of important forest patches that are essential habitats for endemic and endangered species. We present the first list of the medium and large-bodied mammals of RPPN Recanto das Antas from a heterogeneous landscape of Atlantic Forest in Espírito Santo, Brazil. We conducted cameratrapping surveys in 2015 in RPPN Recanto das Antas and adjacent areas in different habitats. We also made opportunistic records from direct observations during fieldwork. We recorded at least 21 wild mammals and two domestic species, comprising nine orders. In total, eight of these species are threatened with extinction according to State, National or Global (IUCN) red lists. RPPN Recanto das Antas is an important area for threatened large-bodied mammals and, along with the protected areas, it can help maintaining the biodiversity of the region, connecting the native forested areas of the landscape.
\end{abstract}

Keywords: Atlantic forest; camera trap; mammalia; protected areas; survey.

\section{INTRODUCTION}

Preserving significant tracts of forest is an important strategy for biodiversity conservation (Bruner et al. 2001, Geldmann et al. 2013, Gray et al. 2016), especially when natural areas occur in an anthropogenic landscape (Koh \& Gardner 2010, Martin et al. 2014). A key tool that can contribute to the effectiveness of species protection is the establishment of protected areas (Rodrigues et al. 2004, Coad et al. 2008, Butchart et al. 2010). In this context, the Private Reserve of Natural Heritage (Reserva Particular do Patrimônio Natural, hereafter "RPPN") is a private protected area, similar to the "International Union for Conservation of Nature" (IUCN) category IV. The goal of this type of protected area is to preserve biological diversity in perpetuity (Brazilian Law 9985/2000 and Decree 5746/2006; Rylands \& Brandon 2005). The RPPNs promote the protection of important forest patches, which are essential habitats for endemic and endangered species (Rylands
\& Brandon 2005), especially in areas under significant threat, such as the Brazilian Atlantic Forest, a global biodiversity hotspot (Myers et al. 2000).

In the north of Espírito Santo, Brazil, a large block of forest represents the last remaining "Tabuleiro Forest" (Rizzini 1997) of the Atlantic Forest, forming part of the Linhares-Sooretama protected area complex. This block of forest is part of the Atlantic Forest Central Corridor and is considered a center of high biological diversity and endemism (Kinzey 1982, Peixoto \& Silva 1997). The region is extremely important for the conservation of several taxa (Conservation International do Brasil et al. 2000), including large mammals (Galetti et al. 2009). Four natural protected areas are present in the region Sooretama Biological Reserve, Vale Natural Reserve, RPPN Mutum-Preto and RPPN Recanto das Antas. This latter was established in 2007, connecting the three other aforementioned protected areas, and thereby protect several charismatic and threatened species in the area, such as the lowland tapir (Tapirus terrestris). 
The region is considered of high importance for mammal conservation (Galetti et al. 2009), and published inventories about the medium and largebodied mammals are only available for Vale Natural Reserve (e.g., Srbek-Araujo et al. 2014, Srbek-Araujo \& Kierulff 2016) and Sooretama Biological Reserve (Chiarello 1999). A complete list of mammal species for the RPPN Recanto das Antas has not been published. Therefore, it is important to gather information on the fauna in this protected area that is part of the Sooretama-Linhares complex, especially for RPPN Recanto das Antas which connects them. Hence, here, we present the first list of medium and large-bodied mammals occurring in RPPN Recanto das Antas and its surroundings.

\section{MATERIAL AND METHODS}

\section{Study site}

We conducted our study in RPPN Recanto das Antas (1950'S, 3958' W; 2,212 ha), which is owned by FIBRIA Celulose S.A., and in its direct surroundings (an estimated area of 5,618 ha), in the municipality of Linhares, Espírito Santo State, Brazil (Figure 1). The study area mostly consists of discontinuous primary vegetation, with a matrix interspersed with extensive eucalyptus and papaya plantations, cabruca (cacao trees planted in the shade of thinned native forest), seringal (rubber tree culture), and smaller amounts of coffee plantations and cattle pastures that are not part of the RPPN Recanto das Antas. Unpaved roads used for eucalyptus harvesting and transportation also traverse the area. RPPN Recanto das Antas is contiguous with the federally-owned Sooretama Biological Reserve (SBR - 27,858.68 ha), the private Vale Natural Reserve (VNR - 22,711.20 ha), and the RPPN Mutum-Preto (379 ha). Together, the four protected areas from the Linhares-Sooretama complex form a forest block of more than $500 \mathrm{~km}^{2}$, the most important complex in the north of the State of Espírito Santo. The vegetation is classified as lowland Ombrophilous Dense Forest (IBGE 1987), also known as Tabuleiro Forest (Rizzini 1997), which dominates the northern coastal portion of the State of Espírito Santo (Peixoto et al. 2008).

\section{Data collection and analysis}

\section{a) Camera-trapping}

We conducted camera-trapping surveys from January to November 2015 in RPPN Recanto das Antas and its adjacent areas. We set camera traps at stations 0.5-2 km apart. To place the camera traps (camera stations) at regular intervals, we created grids of $500 \mathrm{x}$ $500 \mathrm{~m}$ superimposed on a map of the study site using a GIS platform. To select the grids, we chose a stratified random sampling method, by which we divided our study area into five monitoring blocks. We placed the camera traps in one monitoring block at a time, and rotated the camera traps among blocks every two months, meaning each block was monitored just once. We started with eleven stations in the first block; eight stations in the second, third and fourth blocks; and then seven stations in the fifth block; a total of 42 camera trap stations during the camera-trapping surveys (Figure 1). Our sampling was not complete for all the stations because camera traps were stolen during our surveys.

Camera stations were placed in different habitats - within and along edges of forest fragments, eucalyptus plantations, marshes and floodplains - at a distance from roads between 1.36 and $689 \mathrm{~m}$. We did not place cameras at potential feeding sites (e.g., fruit trees) that would attract animals, nor did we use chemical attractants. Cameras were continuously active (24 hours a day, except for battery changes or malfunctions) and were set to shoot three pictures for each record, registering both the date and time of each photograph. We checked camera traps approximately every 20-30 days to replace batteries and to download the photos from memory cards.

To estimate the sampling effort, we multiplied the number of camera traps by the number of sampling days (not considering the inactive time, e.g., when cameras stopped because of technical problems or when we changed batteries). Capture success was calculated by dividing the number of records by the sampling effort and multiplying the result by 100 (Srbek-Araujo \& Chiarello 2007). We considered a temporally independent event when: (a) more than one photograph of the same species was obtained at the same station after a period of 1 hour; (b) consecutive photographs from the same station recorded different species or clearly 


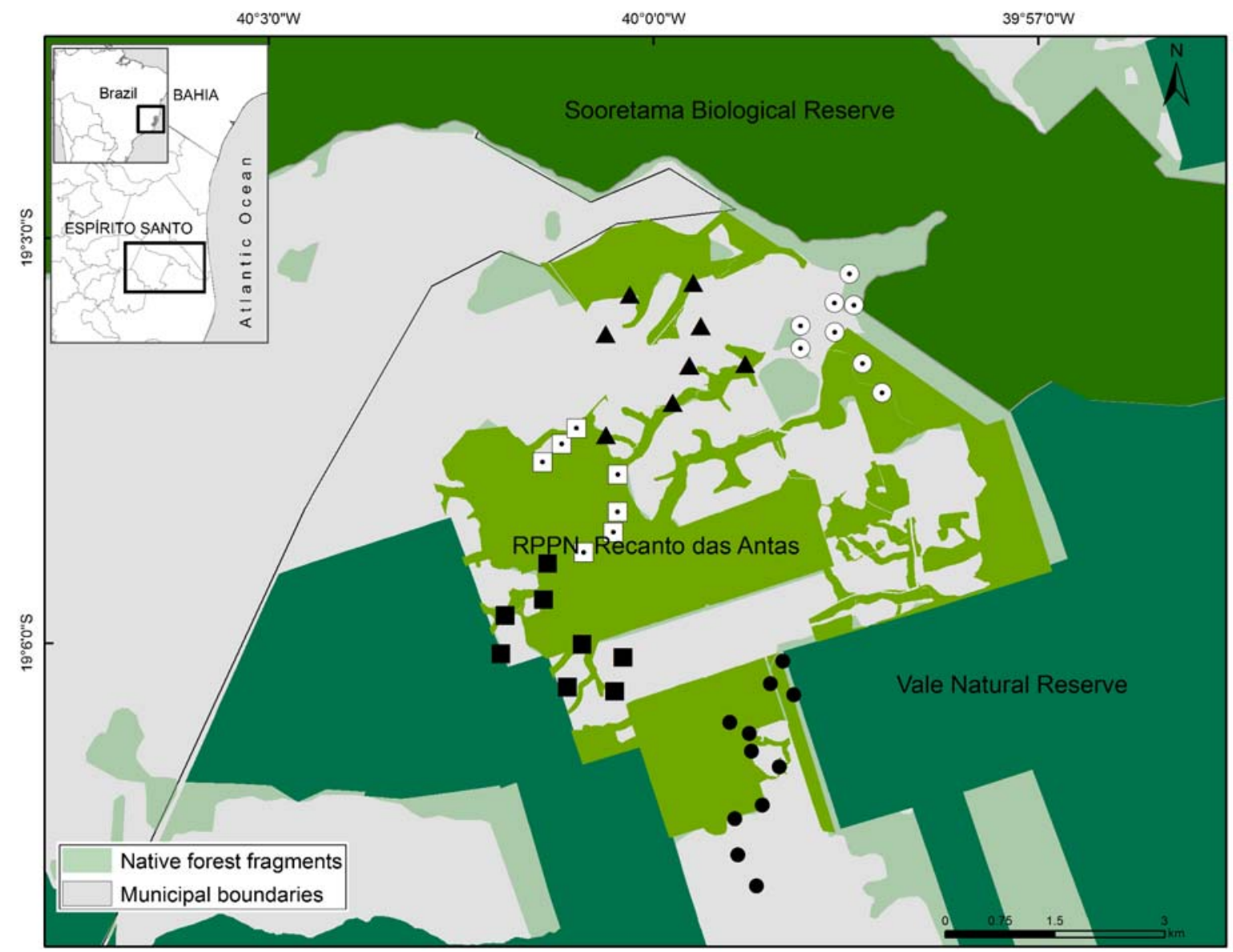

Figure 1. The Private Reserve of Natural Heritage Recanto das Antas (RPPN Recanto das Antas) in Linhares, State of Espírito Santo, Brazil, and locations of the camera trap stations distributed in five blocks (installed from January to November 2015): block one (black circles), block two (white circles), block three (black triangles), block four (black squares), block 5 (white squares). Datum: WGS 1984. Coordinate system/projection: UTM 24S. Cartographic base: Protected areas - (Cadastro Nacional de Unidades de Conservação 2015); Political boundaries - (IBGE 2001, 2005).

distinguishable individuals; (c) photographs from the same station were not consecutive; and (d) when a group of individuals of the same species was recorded, each individual was considered a single record (Wallace et al. 2012, Pérez-Irineo \& Santos-Moreno 2016). We checked the camera trap sampling sufficiency using species accumulation curves, following Colwell et al. (2012).

Photos are provided for each species, including photos of species endemic from the Atlantic Forest and endangered species. Identification and taxonomic nomenclature followed recent mammal compilations (Paglia et al. 2012, Patton et al. 2015, Kitchener et al. 2017). Because of uncertainties in distinguishing two brocket deer species (Mazama americana and M. gouazoubira), two armadillo species (Dasypus novemcinctus and $D$. septemcinctus), and the small cats
(Leopardus guttulus and L. wiedii) in some photographs, we pooled their respective records into three taxa, i.e., Mazama spp., Dasypus spp. and Leopardus spp. We followed Chiarello (2000a) in considering species with a body weight $\geqslant 1 \mathrm{~kg}$ as a medium-bodied mammal, and Carbone et al. (1999) who defined large-bodied species as having body weights $>20 \mathrm{~kg}$. To assess risk/threatened status, we consulted the red list of the State of Espírito Santo (Passamani \& Mendes 2007), the Brazilian red list (Ministério do Meio Ambiente 2014, ICMBio 2016) and the IUCN Red List (IUCN 2016).

\section{b) Opportunistic records}

We made opportunistic records from direct observations of medium and large-bodied mammals during camera-trapping fieldwork (average of five days for each month of monitoring) and two capture campaigns 
aimed at the lowland tapir (in July and October 2015, each involving 15 days of fieldwork). For each event, we recorded the species, number of individuals, gender (when possible), time, locality and type of habitat where the species was observed. We received permits to conduct the study from SISBIO/Instituto Chico Mendes de Conservação da Biodiversidade (number 32565-5).

\section{RESULTS}

We recorded at least 21 mammal species, from nine orders and 17 families, in the RPPN Recanto das Antas and its surrounding areas, considering both camera trapping and opportunistic observations (Table 1 and Figures 2 and 3). In addition, two domestic (or invasive) species were also recorded during sampling: Canis lupus familiaris (Carnivora) and Bos taurus
(Cetartiodactyla) (Figure 4).

We captured at least 19 species using camera traps, seven of which were exclusively recorded by this method (Table 1): Dasypus novemcinctus, Euphractus sexcinctus, Herpailurus yagouaroundi, Leopardus spp., Procyon cancrivorus, Puma concolor, and Tamandua tetradactyla. From a total of 2,149 trap days, we recorded 1,679 independent photographs, resulting in a total capture success of 78.1\%. Tapirus terrestris was the species with the highest capture success (14.4\%), followed by Dasyprocta leporina (11.4\%) and Mazama spp. (9.4\%). The species with the lowest capture success were the small wild cats of genus Leopardus (4.0\%), Euphractus sexcinctus (3.0\%), Herpailurus yagouaroundi (3.0\%), Puma concolor (3.0\%), and Callicebus personatus (1.0\%). We recorded three independent photographs of domestic

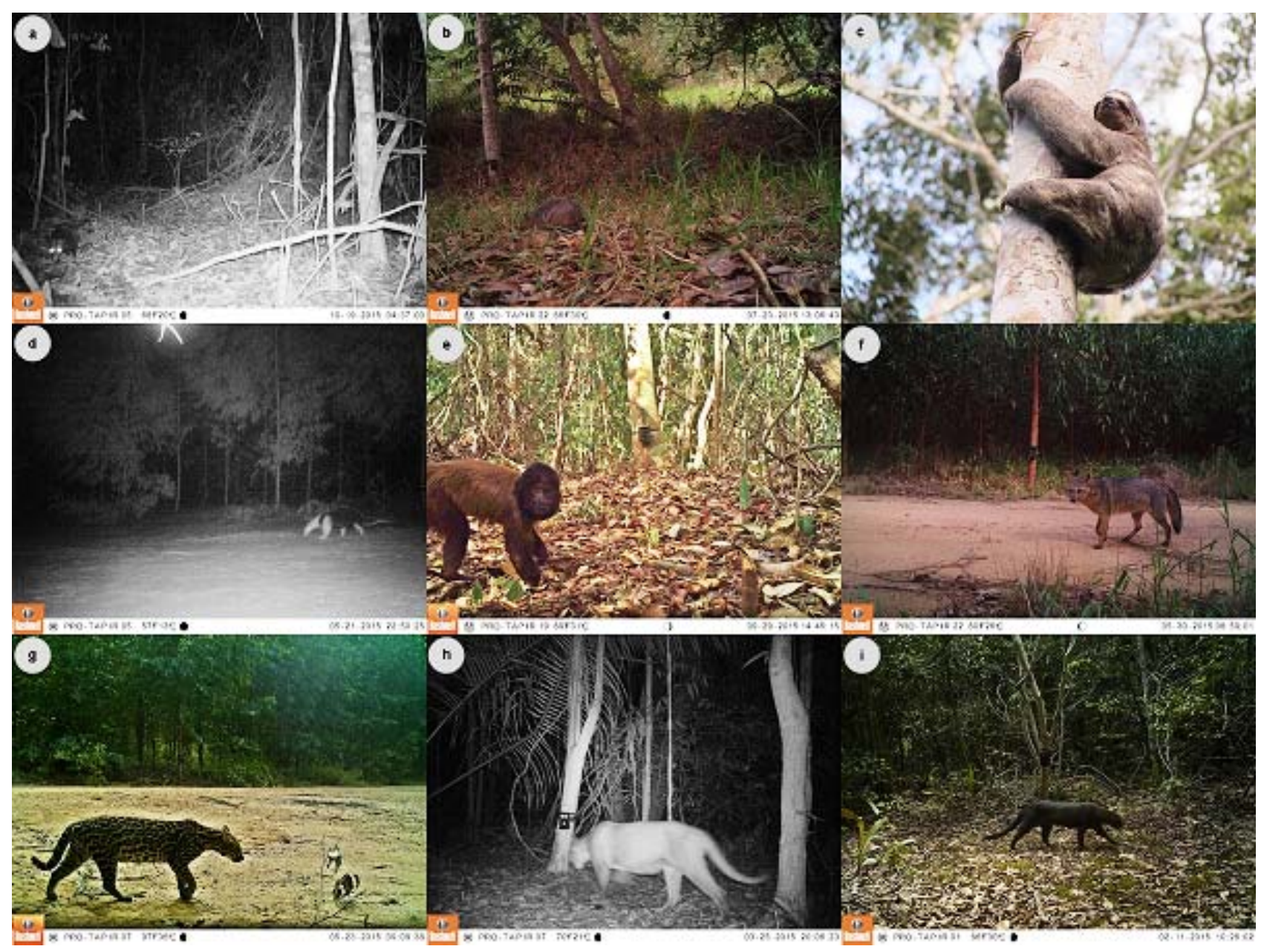

Figure 2. Mammal species recorded in the Private Reserve of Natural Heritage Recanto das Antas (RPPN Recanto das Antas) and its surroundings, municipality of Linhares, State of Espírito Santo, Brazil, from January to November 2015: Didelphis aurita (a); Dasypus novemcinctus (b); Bradypus variegatus (c); Tamandua tetradactyla (d); Sapajus robustus (e); Cerdocyon thous (f); Leopardus pardalis (g); Puma concolor (h); Herpailurus yagouaroundi (i). 
dogs and five of cattle. The species accumulation curves showed sampling sufficiency after 33 sampling units (Figure 5). Our opportunistic observations yielded 16 species records, but only two species - Bradypus variegatus and Sylvilagus brasiliensis - were recorded exclusively by this method.
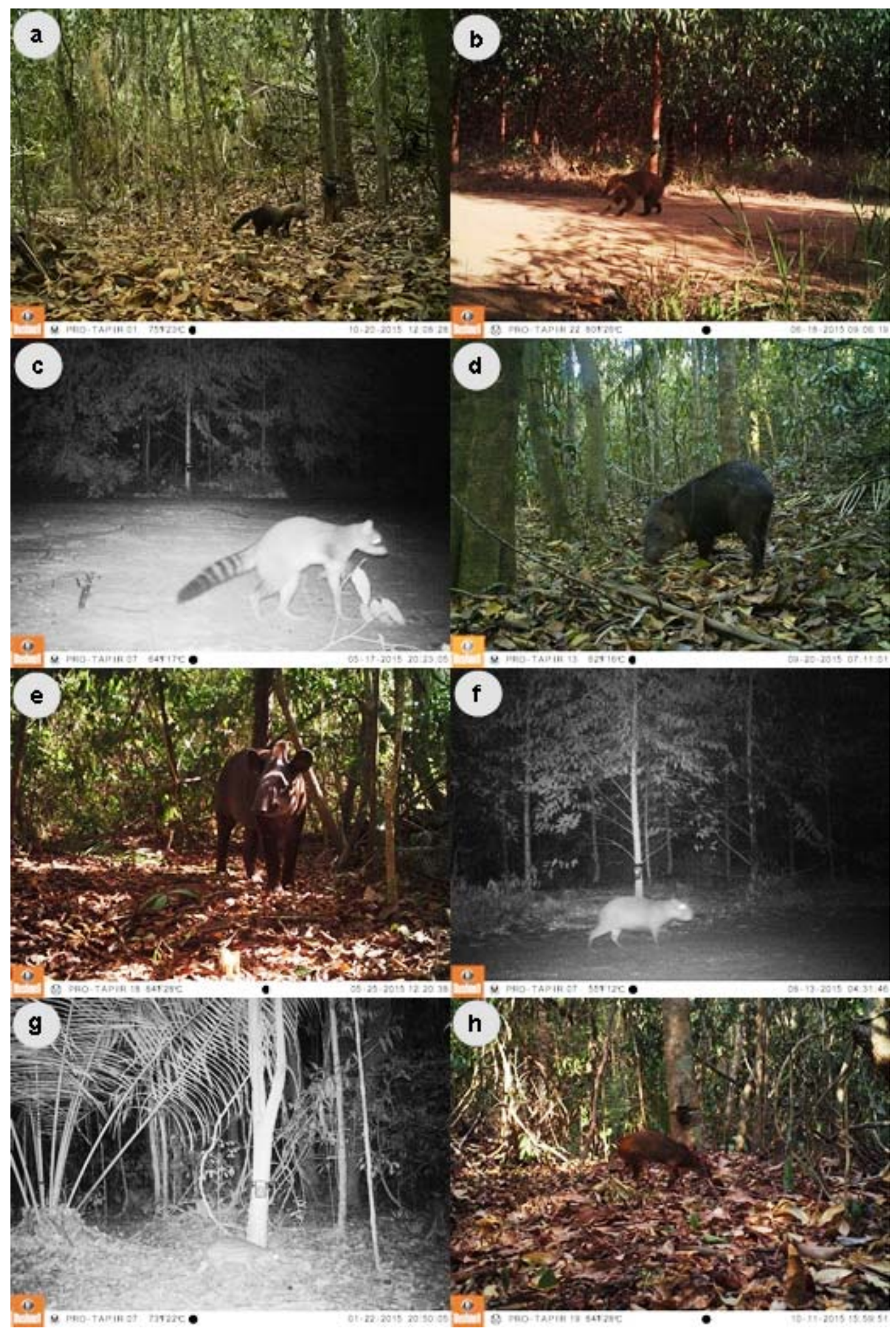

Figure 3. Mammal species recorded in the Private Reserve of Natural Heritage Recanto das Antas (RPPN Recanto das Antas) and its surroundings, municipality of Linhares, State of Espírito Santo, Brazil, from January to November 2015: Eira barbara (a); Nasua nasua (b); Procyon cancrivorus (c); Pecari tajacu (d); Tapirus terrestris (e); Hydrochoerus hydrochaeris (f); Cuniculus paca (g); Dasyprocta leporina (h). 


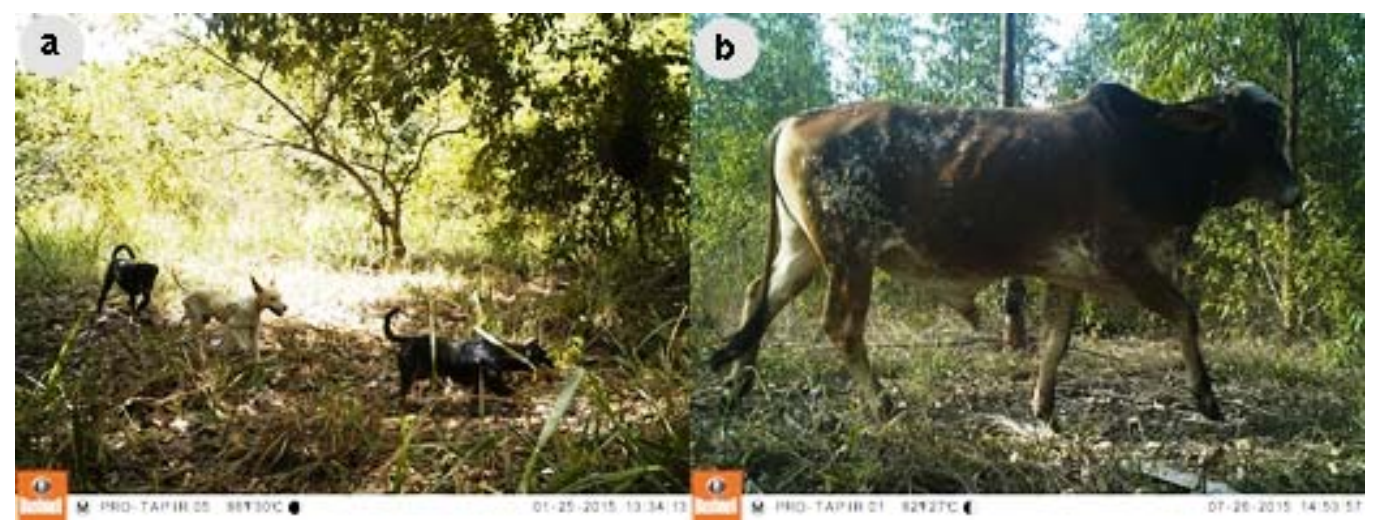

Figure 4. Invasive species recorded in the Private Reserve of Natural Heritage Recanto das Antas (RPPN Recanto das Antas) and its surroundings, in Linhares, Espírito Santo, Brazil, from January to November 2015: Canis lupus familiaris (a); Bos taurus (b).

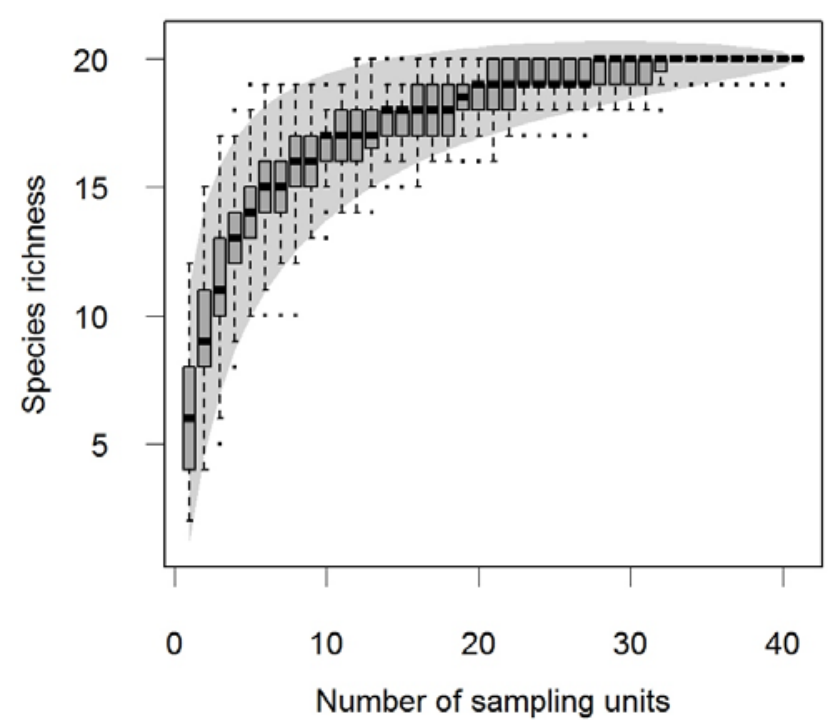

Figure 5. Species accumulation curves relating the number of species $(\mathrm{N}=21)$ and the 42 sampled unities (i.e., number of camera trap stations), showing the sampling sufficiency of the camera trap method, from January to November 2015, in the Private Reserve of Natural Heritage Recanto das Antas (RPPN Recanto das Antas) and its surroundings, municipality of Linhares, State of Espírito Santo, Brazil.

In total, eight of the recorded species are threatened with extinction based on state, national or international red lists. Seven of the species (Vulnerable $=5$; Endangered $=2$ ) are threatened with extinction in the State of Espírito Santo, five species (Vulnerable = 4; Endangered $=1$ ) are at risk according to the Brazilian red list, and three are represented in the IUCN's threatened list $($ Vulnerable $=2$; Endangered $=1)$ (Table 1). We recorded three endemic species of the Atlantic Forest two primates, Callicebus personatus and Sapajus robustus, and a marsupial, Didelphis aurita.

\section{DISCUSSION}

The RPPN Recanto das Antas and its direct surrounding areas harbor about $32.0 \%$ of the medium and large-bodied terrestrial mammals of the Atlantic Forest (following Paglia et al. 2012) and 52.0\% of that of the State of Espírito Santo (following Moreira et al. 2008). Previous fauna inventories carried out in different environments in Espírito Santo, including restinga (Venturini et al. 1996), lowland Ombrophilous Dense Forest (Chiarello 1999, Srbek-Araujo et al. 2014, Srbek-Araujo \& Kierulff 2016), disturbed secondary forest (Passamani et al. 2005), and Montane and Sub-montane Atlantic Forest (Passamani et al. 2000, Srbek-Araujo \& Chiarello 2005, 2007, Tonini et al. 2010, Gatti et al. 2014, Helder-José et al. 2016), recorded between 10 and 36 species of medium and large-bodied mammals. The region with the highest richness of medium and large-bodied wild mammals, recorded for the state, is the Linhares-Sooretama forest complex, which confirms the area as a priority for conservation of this group (see Galetti et al. 2009).

The number of mammal species we recorded for RPPN Recanto das Antas is a similar subset to that of VNR and SBR, in which 36 species of medium and large-bodied mammals have been reported, including species not recorded in the present study like Alouatta guariba, Dasypus septemcinctus, Leopardus guttulus, Leopardus wiedii, Lontra longicaudis, Mazama americana, Mazama gouazoubira, Panthera onca, Potos flavus, Priodontes maximus, and Tayassu pecari (Chiarello 1999, Srbek-Araujo et 
al. 2014, Srbek-Araujo \& Kierulff 2016). Therefore, we recorded at least $58.0 \%$ of the medium and largebodied mammal species expected for the LinharesSooretama complex. Considering that our study area is located in the center of the Linhares-Sooretama complex, we expect that the number of mammals in RPPN Recanto das Antas is in fact higher than reported in this study, which reinforces the importance of RPPN Recanto das Antas in maintaining functional connectivity between the surrounding protected areas.

The presence of top predators within the study area, such as Puma concolor, indicates that RPPN Recanto das Antas still possesses a diversity of prey species and/or permits the movement of predators, such as large felids, that require large areas to survive (Carbone \& Gittleman 2002, de la Torre et al. 2017). The growth and survivorship of individuals of many species, as well as their ability to move between forest fragments, can be influenced by the presence of other habitat patches and the type of landscape matrix (Saura et al. 2014).

We also recorded key seed-dispersing species in RPPN Recanto das Antas, such as Callicebus personatus, Cerdocyon thous, Dasyprocta leporina, Pecari tajacu, Procyon cancrivorus, Sapajus robustus, and Tapirus terrestris. Such species are important for plant recruitment and survival, and aid in forest regeneration (Gatti et al. 2006, Chapman \& Russo 2007, Keuroghlian \& Eaton 2008, Tobler et al. 2010, Pires \& Galetti 2012, Bueno et al. 2013, Chalukian et al. 2013). Of particular importance is the lowland tapir, a megafrugivore that disperses the seeds of several plant species (Tobler et al. 2010, Bueno et al. 2013, Giombini et al. 2016).

The RPPN Recanto das Antas represents part of the last-remaining region of the State of Espírito Santo where iconic threatened mammalian species of the Atlantic Forest can still be found. For example, here, we report the occurrence of some threatened and endemic species of the Atlantic Forest in the complex, such as Callicebus personatus, Puma concolor, Sapajus robustus, and Tapirus terrestris. Chiarello (1999), SrbekAraujo et al. (2014) and Srbek-Araujo \& Kierulff (2016), also reported the presence of Panthera onca, Priodontes maximus and Tayassu pecari. Large herbivores and carnivores are generally the first mammal species to go locally extinct in Neotropical forests (Canale et al. 2012,
Dirzo et al. 2014, Ripple et al. 2015), because of their need for large home ranges and their intrinsic biological traits, such as naturally low densities and low reproductive rates (Cardillo et al. 2005).

For these reasons, RPPN Recanto das Antas is an important area for the medium and large threatened and endemic mammals in the Linhares-Sooretama complex. However, like other parts of the Atlantic Forest, RPPN Recanto das Antas is not free from threats. Several risks for the region have been reported, such as hunting, road-kill and conflict with farmers, all of which can increase the potential of regional extinctions (Chiarello 2000b, Flesher \& Gatti 2010, Srbek-Araujo et al. 2014, Srbek-Araujo \& Kierulff 2016, A. Gatti personal communication).

In addition, the presence of domestic species in the study area is an imminent threat. Domestic dogs and cattle can interact with the local fauna through competition, predation and pathogen transmission that can cause severe impacts on different species populations (Daszak et al. 2000, Delahay et al. 2001, Gortazar et al. 2007, Atickem et al. 2010, Hughes \& Macdonald 2013, Kukielka et al. 2013). In some regions of Atlantic Forest, domestic/feral dogs are frequent visitors to natural forest fragments, including protected areas (Srbek-Araujo \& Chiarello 2008, Lacerda et al. 2009, Paschoal et al. 2012, Gatti et al. 2014, Lessa et al. 2016). Given these several threats to the medium and large-bodied mammals of the Linhares-Sooretama complex, it is important not only to know the diversity of species in a given area, but also to monitor the threats to their populations.

The relevance of our results can be summarized as follows: (1) surveys of small or medium sized habitat patches that connect larger patches can provide important information on the presence of medium and large-bodied mammals in the overall landscape; (2) RPPN Recanto das Antas merits ecological studies to understand how its medium and large-bodied mammals use different habitats and move through its heterogeneous landscape, especially for species that typically have large home ranges; and (3) because several threats coincide in the study area, it is important to evaluate the adaptations of different species to the diverse anthropogenic pressures in the landscape, which could help to develop a sustainable wildlife management and conservation plan for RPPN Recanto das Antas and the surrounding protected areas. 
Table 1. Medium and large-bodied mammals species recorded in the Private Reserve of Natural Heritage Recanto das Antas using the methods of sighting (SI) and camera trap (CT), including the number of independent records from camera traps (IR). Conservation status is provided at State (ES), national (BR) and global (IUCN) levels, considering the threat categories: LC = Least Concern; VU = Vulnerable; EN = Endangered. “Und.” = Undetermined. “-” = information not available.

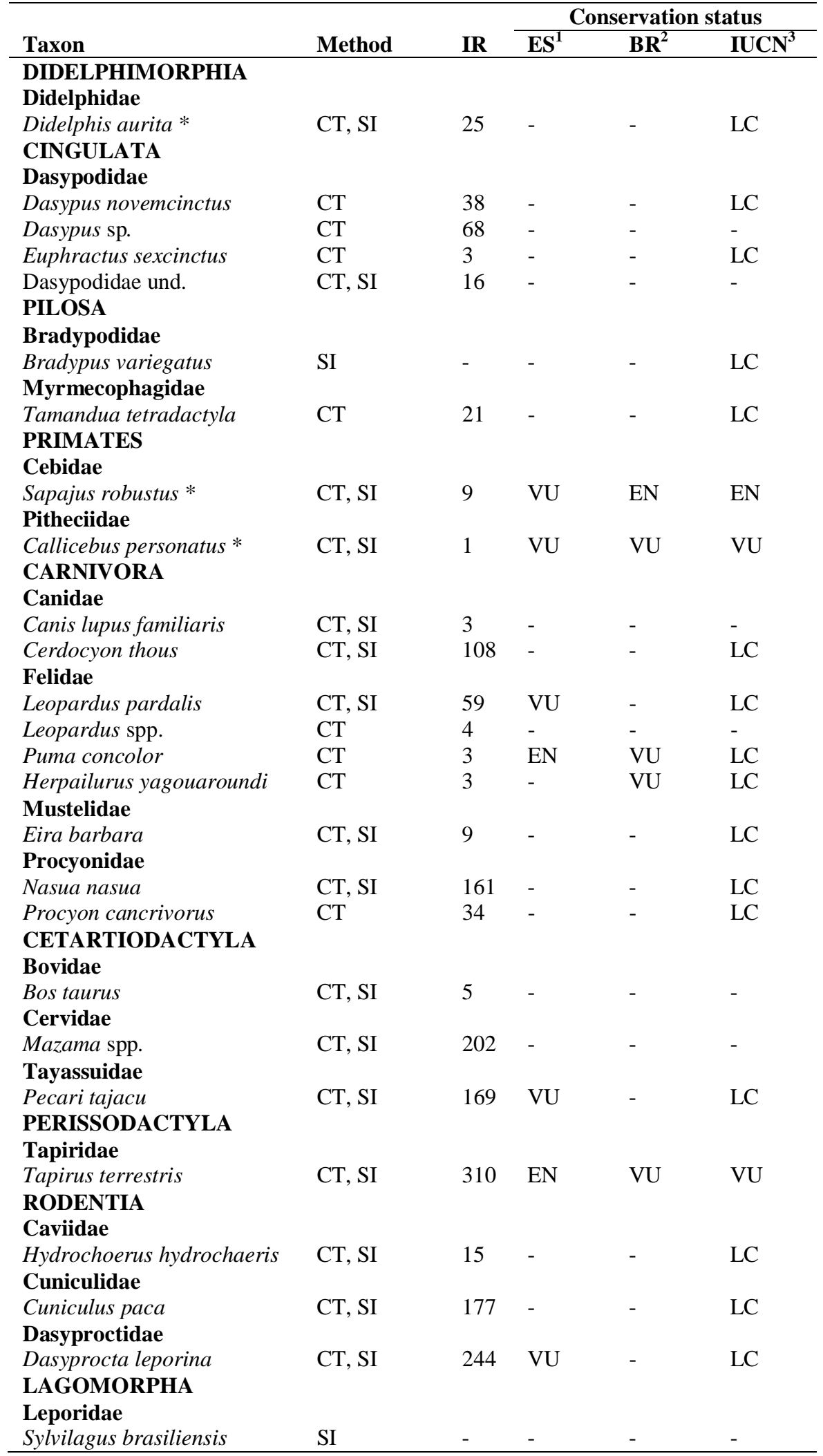

${ }^{1}$ Threatened species at state level, following Chiarello et al. (2007); ${ }^{2}$ Threatened species at national level, following MMA (2014); ${ }^{3}$ Threatened species at global level, following IUCN (2016); *Endemic species. 


\section{ACKNOWLEDGEMENTS}

The authors are grateful to Paulo Rogério Mangini, Joana Zorzal Nodari, Amabili Falqueto Mistura, Cristina López Malaga, Dahiani Nunes Bossi, José Roberto Oliveira and Cupido \& Refúgio Farm. This research had the financial support of Fibria Celulose S.A., Instituto Estadual de Meio Ambiente e Recursos Hídricos (IEMA, process number 9003/2014) and Idea Wild. AG received a postdoctoral fellowship from Coordenação de Aperfeiçoamento de Pessoal de Nível Superior (CAPES/Brazil).

\section{REFERENCES}

Atickem, A., Bekele, A., \& Williams, S. D. 2010. Competition between domestic dogs and Ethiopian wolf (Canis simensis) in the Bale Mountains National Park, Ethiopia. African Journal of Ecology, 48(2), 401-407. DOI: 10.1111/j.13652028.2009.01126. $\mathrm{X}$

Bruner, A. G., Gullison, R. E., Rice, R. E., \& Fonseca, G. A. B da. 2001. Effectiveness of parks in protecting tropical biodiversity. Science 291: 125-128. DOI: 10.1126/ science.291.5501.125

Bueno, R. S., Guevara, R., Ribeiro, M. C., Culot, L., Bufalo, F. S., \& Galetti, M. 2013. Functional redundancy and complementarities of seed dispersal by the last Neotropical Megafrugivores. PLoS One, 8(2), e56252. DOI: 10.1371/ journal.pone.0056252

Butchart, S. H. M., Walpole, M., Collen, B., van Strien, A., Scharlemann, J. P. W., Almond, R. E. A., Baillie, J. E. M., Bomhard, B., Brown, C., Bruno, J., Carpenter, K. E., Carr, G. M., Chanson, J., Chenery, A. M., Csirke, J., Davidson, N. C., Dentener, F., Foster, M., Galli, A., Galloway, J. N., Genovesi, P., Gregory, R. D., Hockings, M., Kapos, V., Lamarque, J. F., Leverington, F., Loh, J., McGeoch, M. A., McRae, L., Minasyan, A., Morcillo, M. H., Oldfield, T. E. E., Pauly, D., Quader, S., Revenga, C., Sauer, J. R., Skolnik, B., Spear, D., Stanwell-Smith, D., Stuart, S. N., Symes, A., Tierney, M., Tyrrell, T. D., Vie, J. C., \& Watson, R. 2010. Global biodiversity: indicators of recent declines. Science, 328, 11641168. DOI: $10.1126 /$ science. 1187512

Cadastro Nacional de Unidades de Conservação. 2015. Unidades de Conservação do Brasil [map]. Ministério do Meio Ambiente, 1:5.000 a 1:100.000. Brasília: Ministério do Meio Ambiente. Retrieved 18 December, 2016, from http://mapas.mma.gov.br/ i3geo/datadownload.htm

Canale, G. R., Peres, C. A., Guidorizzi, C. E., Gatto, C. A. F., \& Kierulff, M. C. M. 2012. Pervasive defaunation of forest remnants in a Tropical Biodiversity Hotspot. Plos One, 7(8), e41671. DOI: 10.1371/journal.pone.0041671

Carbone, C., \& Gittleman, J. L. 2002. A common rule for the scaling of carnivore density. Science, 295, 2273-2276. DOI: 10.1126/science.1067994

Carbone, C. G, Mace, G., Roberts, S. C., \& MacDonald, D. W. 1999. Energetic constraints on the diet of terrestrial carnivores. Nature, 402, 286-288. DOI: 10.1038/46266

Cardillo, M., Mace, G. M., Jones, K.E., Bielby, J., BinindaEmonds, O. R. P., Sechrest, W., Orme, C. D. L., \& Purvis, A. 2005. Multiple causes of high extinction risk in large mammal species. Science, 309, 1239-1241. DOI: 10.1126/ science. 1116030

Chalukian, S. C., Bustus, M. S., \& Lizárraga, R. L. 2013. Diet of lowland tapir (Tapirus terrestris) in El Rey National Park, Salta, Argentina. Integrative Zoology, 8, 48-56. DOI: 10.1111/ j.1749-4877.2012.12009.x

Chapman, C. A., \& Russo, S. E. 2007. Primate seed dispersal: Linking behavioural ecology and forest community structure. In: C. J. Campbell, A. F. Fuentes, K. C. MacKinnon, M. Panger, \& S. Bearder (Eds.), Primates in perspective. pp. 510-525. New York: Oxford University Press.

Chiarello, A. G. 1999. Effects of fragmentation of the Atlantic forest on mammal communities in southeastern Brazil. Biological Conservation, 89(1), 71-82. DOI: 10.1016/S00063207(98)00130-X.

Chiarello, A. G. 2000a. Density and population size of mammals in remnants of Brazilian Atlantic Forest. Conservation Biology, 14(6), 1649-1657. DOI: 10.1111/j.1523-1739.2000.99071.x

Chiarello, A. G. 2000b. Influência da caça ilegal sobre mamíferos e aves das matas de tabuleiro do norte do estado do Espírito Santo. Boletim do Museu de Biologia Mello Leitão, 11(12), 229-247.

Coad, L., Burgess, N. D., Fish, L., Ravillious, C., Corrigan, C., Pavese, H., Granziera, A., \& Besançon, C. 2008. Progress towards the convention on biological diversity terrestrial 2010 and marine 2012 targets for protected area coverage. Parks, 17, 35-42.

Colwell, R. K., Chao, A., Gotelli, N. J., Lin, S. Y., Mao, C. X., Chazdon, R. L., \& Longino, J. T. 2012. Models and estimators linking individual-based and sample-based rarefaction, extrapolation, and comparison of assemblages. Journal of Plant Ecology, 5(1), 3-21.

Conservation International do Brasil. 2000. Avaliação e ações prioritárias para a conservação da biodiversidade da Mata Atlântica e Campos Sulinos. Conservation International do Brasil, Fundação SOS Mata Atlântica, Fundação Biodiversitas, Instituto de Pesquisas Ecológicas, Secretaria do Meio Ambiente do Estado de São Paulo \& SEMAD/Instituto Estadual de Florestas-MG. Brasília: MMA/ SBF: p. 40.

Daszak, P., Cunningham, A. A., \& Hyatt, A. D. 2000. Emerging infectious diseases of wildlife - threats to biodiversity and human health. Science, 287, 443-449. DOI: 10.1126/ science.287.5452.443

Delahay, R. J., Cheeseman, C. L., \& Clifton-Hadley, R. S. 2001. Wildlife disease reservoirs: the epidemiology of Mycobacterium bovis infection in the European badger (Meles meles) and other British mammals. Tubercolosis, 81(1-2), 4349. DOI: $10.1054 /$ tube.2000.0266

de la Torre, J. A., Núñez, J. M., \& Medellín, R. A. 2017. Spatial requirements of jaguars and pumas in Southern Mexico. Mammalian Biology, 84, 52-60. DOI: 10.1016/ j.mambio.2017.01.006

Dirzo, R., Young, H. S., Galetti, M., Ceballos, G., Isaac, N. J. B., \& Collen, B. 2014. Defaunation in the Anthropocene. Science, 345(6195), 401-406. DOI: 0.1126/science.1251817

Flesher, K. M., \& Gatti, A. 2010. Tapirus terrestris in Espírito Santo, Brazil. Tapir Conservation, 19/1(26), 16-23. 
Galetti, M., Giacomini, H. C., Bueno, R. S., Bernardo, C. S. S., Marques, R. M., Bovendorp, R. S., Steffler, C. E., Rubim, P., Goboo, S. K., Donatti, C. I., Begotti, R. A., Meirelles, F., Nobre, R. A., Chiarello, A. G., \& Peres, C. A. 2009. Priority areas for conservation of Atlantic Forest large mammals. Biological Conservation, 142(6), 1229-1241. DOI: 10.1016/ j.biocon.2009.01.023

Gatti, A., Bianchi, R., Rosa, C. R. X., \& Mendes, S. L. 2006. Diet of two sympatric carnivores, Cerdocyon thous and Procyon cancrivorus, in a restinga area of Espirito Santo State, Brazil. Journal of Tropical Ecology, 22(2), 227-230. DOI: 10:10.1017/ S026646705002956

Gatti,A., Segatto, B., Carnelli, C. C. \& Moreira, D. O. 2014. Mammals of medium and large size from Reserva Biológica Augusto Ruschi, Espírito Santo. Natureza on line, 12(2), 61-68.

Geldmann, J., Barnes, M., Coad, L., Craigie, I. D., Hockings, M., \& Burgess, N. D. 2013. Effectiveness of terrestrial protected areas in reducing habitat loss and population declines. Biological Conservation, 161, 230-238. DOI: 10.1016/ j.biocon.2013.02.018

Giombini, M. I., Bravo, S. P., \& Tosto, D. S. 2016. The key role of the largest extant Neotropical frugivore (Tapirus terrestris) in promoting admixture of plant genotypes across the landscape. Biotropica, 48(4), 499-508. DOI: 10.1111/btp.12328

Gortazar, C., Ferroglio, E., Höfle, U., Frölich, K., \& Vicente, J. 2007. Diseases shared between wildlife and livestock: a European perspective. European Journal of Wildlife Research, 53(4), 241-256. DOI: 10.1007/s10344-007-0098-y

Gray, C. L., Hill, S. L. L., Newbold, T., Hudson, L. N., Börger, L., Contu, S., Hoskins, A. J., Ferrier, S., Purvis, A., \& Scharlemann, J. P. W. 2016. Local biodiversity is higher inside than outside terrestrial protected areas worldwide. Nature Communications, 7, 12306. DOI: 10.1038/ncomms12306

Helder-José, Zortéa, M., Passamani, J. A., Mendes, S. L., \& Passamani, M. 2016. Mammals from Duas Bocas Biological Reserve, state of Espírito Santo, Brazil. Boletim do Museu de Biologia Mello Leitão, 38(2), 163-180.

Hughes, J., \& Macdonald, D. W. 2013. A review of the interactions between free-roaming domestic dogs and wildlife. Biological Conservation, 157, 341-351. DOI: 10.1016/j.biocon.2012.07.005

IBGE. 1987. Folha SE 24 Rio Doce: geologia, geomorfologia, pedologia, vegetação, uso potencial da terra. Projeto RADAM. Rio de Janeiro: Instituto Brasileiro de Geografia e Estatística (IBGE): p. 544.

IBGE. 2001. Limites estaduais do Brasil [map]. Departamento de cartografia, 1:2 500 000. Brasília: Instituto Brasileiro de Geografia e Estatística (IBGE). Retrieved 18 December, 2016, from http://mapas.mma.gov.br/i3geo/datadownload.htm

IBGE. 2005. Malha municipal digital do Brasil [map]. Diretoria de Geociências, 1:2.500.000. Brasília. Instituto Brasileiro de Geografia e Estatística (IBGE). Retrieved 18 December, 2015, from http://mapas.mma.gov.br/i3geo/datadownload.htm

ICMBio. 2016. Sumário executivo do livro vermelho da fauna brasileira ameaçada de extinção. Brasília: Instituto Chico Mendes de Conservação da Biodiversidade (ICMBio): p. 76.

IUCN. 2016. The IUCN Red List of Threatened Species. Version 2016-3. International Union for Conservation of Nature.
Retrieved 7 December, 2016, from http://www.iucnredlist.org Keuroghlian, A., \& Eaton, D. P. 2008. Fruit availability and peccary frugivory in an isolated Atlantic forest fragment: effects on peccary ranging behavior and habitat use. Biotropica, 40(1), 62-70. DOI: 10.1111/j.1744-7429.2007.00351.x

Kinzey, W. G. 1982. Distribution of primates and forest refuges. In: G. T. Prance (Ed.), Biological Diversification in the Tropics. pp. 455-48. New York: Columbia University Press.

Kitchener, A. C., Breitenmoser-Würste, Ch., Eizirik, E., Gentry, A., Werdelin, L., Wilting, A., Yamaguchi, N., Abramov, A. V., Christiansen, P., Driscoll, C., Duckworth, J. W., Johnson, W., Luo, S. J., Meijaard, E., O’Donoghue, P., Sanderson, J., Seymour, K., Bruford, M., Groves, C., Hoffmann, M., Nowell, K., Timmons, Z., \& Tobe, S. 2017. A revised taxonomy of the Felidae. The final report of the Cat Classification Task Force of the IUCN/SSC Cat Specialist Group. Cat News Special, Issue 11: p. 80.

Koh, L. P., \& Gardner, T. A. 2010. Conservation in human-modified landscapes. In: N. S. Sodhi, \& P. R. Ehrlich (Eds.), Conservation biology for all. pp. 236-261. UK: Oxford University Press.

Kukielka, E., Barasona, J. A., Cowie, C. E., Drewe, J. A., Gortazar, C., Cotarelo, I., \& Vicente, J. 2013. Spatial and temporal interactions between livestock and wildlife in South Central Spain assessed by camera traps. Preventive Veterinary Medicine, 112(3-4), 213-21. DOI: 10.1016/ j.prevetmed.2013.08.008

Lacerda, A. C. R., Tomas, W. M., \& Marinho-Filho, J. 2009. Domestic dogs as an edge effect in the Brasília National Park; Brazil: interactions with native mammals. Animal Conservation, 12(5), 477-487. DOI: 10.1111/j.14691795.2009.00277.x

Lessa, I., Guimarães, T. C. S, Bergallo, H. de G., Cunha, A., \& Vieira, E. M. 2016. Domestic dogs in protected areas: a threat to Brazilian mammals? Natureza \& Conservação, 14(2), 4656. DOI: 10.1016/j.ncon.2016.05.001

Martin, L. J., Quinn, J. E., Ellis, E. C., Shaw, M. R., Dorning, M. A., Hallett, L. M., Heller, N. E., Hobbs, R. J., Kraft, C. E., Law, E., Michel, N. L., Perring, M. P., Shirey, P. D., \& Wiederholt, R. 2014. Conservation opportunities across the world's anthromes. Diversity and Distributions, 20(7), 745755. DOI: $10.1111 /$ ddi.12220

Ministério do Meio Ambiente. 2014. Portaria n 444/2014. Lista Nacional Oficial de Espécies da Fauna Ameaçada de Extinção. Retrieved 16 December, 2015, from http://www.icmbio.gov.br/ portal/images/stories/biodiversidade/fauna-brasileira/avaliacaodo-risco/PORTARIA_N\%C2\%BA_444_DE_17_DE_ DEZEMBRO_DE_2014.pdf

Moreira, D. O., Coutinho, B. R., \& Mendes, S. L. 2008. O status do conhecimento sobre a fauna de mamíferos do Espírito Santo baseado em registros de museus e literatura científica. Biota Neotropica, 8(2), 163-173.

Myers, N., Mittermeier, R. A., Mittermeier, C. G., Da Fonseca, G. A., \& Kent, J. 2000. Biodiversity hotspots for conservation priorities. Nature, 403(6772), 853-858.

Paglia, A. P., da Fonseca, G. A. B., Rylands, A. B., Herrmann, G., Aguiar, L. M. S., Chiarello, A. G., Leite, Y. L. R., Costa, L. P., Siciliano, S., Kierulff, M. C. M., Mendes, S. L., Tavares, V. da 
C., Mittermeier, R. A., \& Patton, J. L. 2012. Annotated Checklist of Brazilian Mammals, 2nd edition. Occasional Papers in Conservation Biology, 6, 1-77.

Paschoal, A. M. O., Massara, R. L., Santos, J. L., \& Chiarello, A. G. 2012. Is the domestic dog becoming an abundant species in the Atlantic forest? A study case in southeastern Brazil. Mammalia, 76(1), 67-76. DOI: 10.1515/mammalia-2012-0501

Passamani, M., Mendes, S. L., \& Chiarello, A. G. 2000. Nonvolant mammals of the Estação Biológica de Santa Lúcia and adjacent areas of Santa Teresa, Espírito Santo, Brazil. Boletim do Museu de Biologia Mello Leitão (Nova Série), 11, 201-214.

Passamani, M., Dalmaschio, J., \& Lopes, S. A. 2005. Mamíferos não-voadores em áreas com predomínio de Mata Atlântica da Samarco Mineração S.A., município de Anchieta, Espírito Santo. Biotemas, 18(1), 135-149.

Passamani, M., \& Mendes, S. L. (Eds.) 2007. Espécies da fauna ameaçadas de extinção no Estado do Espírito Santo. VitóriaES: Instituto de Pesquisas da Mata Atlântica: p. 140.

Patton, J. L., Pardiñas, U. F. J., \& D’Elía, G. 2015. Mammals of South America: rodents. Chicago and London: The University of Chicago Press: p. 1336.

Peixoto, A. L., \& Silva, I. M. 1997. Tabuleiro forests of northern Espirito Santo, South-eastern Brazil. In: S. D. Davis, V. H. Heywood, O. Herrera-Macbryde, J. Villa-Lobos, \& A. C. Hamilton (Eds.). Centres of Plant Diversity: A Guide and Strategy for Their Conservation. pp. 369-372. WWF/IUCN.

Peixoto, A. L., Silva, I. M., Pereira, O. J., Simonelli, M., Jesus, R. M., \& Rolim, G. 2008. Tabuleiro Forests north of the Rio Doce: their representation in the Vale do Rio Doce Natural Reserve, Espírito Santo, Brazil. In: W. W. Thomas, \& E. G. Britton (Eds.), The Atlantic Coastal Forest of Northeastern Brazil, v.100. pp. 319-350. Memoirs of the New York Botanical Garden. New York: The New York Botanical Garden Press.

Pérez-Irineo, G., \& Santos-Moreno, A. 2016. Abundance and activity patterns of medium-sized felids (Felidae, Carnivora) In Southeastern Mexico. The Southwestern Naturalist, 61(1), 33-39. DOI: 10.1894/0038-4909-61.1.33

Pires, A. S., \& Galetti, M. 2012. The agouti Dasyprocta leporina (Rodentia: Dasyproctidae) as seed disperser of the palm Astrocaryum aculeatissimum. Mastozoologia Neotropical, 19, 147-153.

Ripple, W. J., Newsome, T. M., Wolf, C., Dirzo, R., Everatt, K. T., Galetti, M., Hayward, M. W., Kerley, G. I. H., Levi, T., Lindsey, P. A., Macdonald, D. W., Malhi, Y., Painter, L. E., Sandom, C. J., Terborgh, J., \& Van Valkenburgh, B. 2015. Collapse of the world's largest herbivores. Science Advances, 1, e1400103. DOI: http://dx.doi.org/10.1126/sciadv.1400103

Rizzini, C. T. 1997. Tratado de fitogeografia do Brasil: aspectos ecológicos, sociológicos e florísticos. 2nd ed. Rio de Janeiro: Âmbito Cultural: p. 521.

Rodrigues, A. S. L., Andelman, S. J., Bakarr, M. I., Boitani, L., Brooks, T. M., Cowling, R. M., Fishpool, L. D. C., Fonseca, G. A. B., Gaston, K. J., Hoffmann, M., Long, J. S., Marquet,
P. A., Pilgrim, J. D., Pressey, R. L., Schipper, J., Sechrest, W., Stuart, S. N., Underhill, L. G., Waller, R. W., Watts, M. E. J., \& Yan, X. 2004. Effectiveness of the global protected area network in representing species diversity. Nature, 428, 640643. DOI: $10.1038 /$ nature02422

Rylands, A. B., \& Brandon, K. 2005. Brazilian protected areas. Conservation Biology, 19(3), 612-618. DOI: 10.1111/j.15231739.2005.00711.x

Saura, S., Bodin, Ö., \& Fortin, M. J. 2014. Stepping stones are crucial for species' long-distance dispersal and range expansion through habitat networks. Journal of Applied Ecology, 214(51), 171-182. DOI: 10.1111/1365-2664.12179

Srbek-Araujo, A. C., \& Chiarello, A. G. 2005. Is camera-trapping an efficient method for surveying mammals in Neotropical forests? A case study in south-eastern Brazil. Journal of Tropical Ecology, 21(1), 121-125. DOI: 10.1017/ S0266467404001956

Srbek-Araujo, A. C., \& Chiarello, A. G. 2007. Use of camera traps in mammal sampling: methodological considerations and comparison of equipments. Revista Brasileira de Zoologia, 24(3), 647-656. DOI: 10.1590/S0101-81752007000300016

Srbek-Araujo, A. C., \& Chiarello, A. G. 2008. Domestic dogs in Atlantic Forest reserves of souh-eastern Brazil: a camera trapping study on patterns of entrance and site occupancy rates. Brazilian Journal of Biology, 68(4), 771-779. DOI: 10.1590/S1519-69842008000400011

Srbek-Araujo, A. C., Rocha, M. F., \& Peracchi, A. L. 2014. A mastofauna da Reserva Natural Vale, Linhares, Espírito Santo, Brasil. Ciência \& Ambiente, 49, 153-167.

Srbek-Araujo, A. C., \& Kierulff, M. C. M. 2016. Mamíferos de médio e grande porte das florestas de Tabuleiro do norte do Espírito Santo: grupos funcionais e principais ameaças. In: S. G. Rolim, L. F. T. de Menezes, \& A. C. Srbek-Araujo (Eds.), Floresta Atlântica de Tabuleiro: diversidade e endemismos na Reserva Natural Vale. pp. 469-479.

Tobler, M. W., Janovec, J. P., \& Cornejo, F. 2010. Frugivory and seed dispersal by the Lowland Tapir Tapirus terrestris in the Peruvian Amazon. Biotropica, 42(2), 215-222. DOI: 10.1111/ j.1744-7429.2009.00549.x

Tonini, J. F. R., Carão, L. M., Pinto, I. S., Gasparini, J. L., Leite, Y. L. R., \& Costa, L. P. 2010. Non-volant tetrapods from Reserva Biológica de Duas Bocas, State of Espírito Santo, Southeastern Brazil. Biota Neotropica 10(3), 339-351. DOI: 10.1590/S1676-06032010000300032

Venturini, A. C., Ofranti, A. M. S., Varejão, J. B. M., \& Paz, P. R. 1996. Aves e Mamíferos na Restinga: Parque Estadual Paulo César Vinha - Setiba, Guarapari, ES. Vitória, Secretaria de Estado de Desenvolvimento Sustentável: p. 68.

Wallace, R., Ayala, G., \& Visacarra, M. 2012. Lowland tapir (Tapirus terrestris) distribution, activity patterns and relative abundance in the Greater Madidi-Tambopata Landscape. Integrative Zoology, 7(4), 407-419. DOI: 10.1111/17494877.12010 